\title{
Endophytes and heat tolerance in lambs grazing perennial ryegrass
}

\section{L.R. FLETCHER, L.J. MARKHAM' and S.R. WHITE AgResearch, PO Box 60, Lincoln ${ }^{1}$ Animal Science Dept., PO Box 84, Lincoln University}

\section{Abstract}

Endophytes in perennial ryegrass protect their hosts against attack by Argentine stem weevil but cause adverse affects, including heat stress, in grazing animals. Ten lambs were grazed on Grasslands Nui ryegrass without endophyte or with its wildtype or a high ergovaline-producing endophyte (196). Five lambs from the 196 treatment were swapped for 5 on the endophyte-free treatment after 20 days. Rectal temperatures and respiration rates were measured daily; on one day they were measured every 2-4 hours. There was a significant difference in respiration rate and body temperature between lambs grazing endophyte and endophytefree treatments but not between the two endophyte treatments. There was no interaction with ambient temperature within the range $12-30^{\circ} \mathrm{C}$. When lambs where transferred from toxic to non-toxic treatments there was no significant decrease in body temperature or respiration rate within 14 days. Ergovaline, even at low concentrations, affects thermo-regulation in lambs and is undesirable in perennial ryegrasslendophyte associations.

K eywords: body temperature, endophyte, ergovaline, heat stress, Lolium perenne, respiration rate

\section{Introduction}

Perennial ryegrass (Lolium perenne L.) is still the basis for the majority of New Zealand's improved pastures. Most of this ryegrass is infected with an endophyte which protects it against the pasture pest Argentine stem weevil (Listronotus bonariensis Kuschel). --However, these same ryegrasslendopbyte associations are responsible for a number of toxic responses in grazing livestock including reduced liveweight gains, ryegrass staggers, decreased prolactin levels, increased faecal moisture, dags and flystrike and increased body (rectal) temperatures and respiration rates (Fletcher et al. 1990; Fletcher 1993a). Several of these toxic responses, including increased body temperatures and respiration rates, also occur in animals grazing tall fescue/endophyte associations. They are almost certainly caused by ergopeptine alkaloids which are produced by both ryegrass and tall fescue endophyte associations
(Fletcher 1993b; Thompson \& Stuedemann 1993; Rowan et al. 1990). Ergovaline is the most abundant of these alkaloids in tall fescue and ryegrass and is a vasoconstrictor which can lead to reduced blood flow to the skin and peripheral tissues in animals grazing toxic pastures (Berde \& Schild 1978; Rhodes et al. 1989; Beleskey et al. 1988). This reduction in blood flow is believed to be responsible for increased body temperatures and respiration rates (Stuedemann $\&$ Thompson 1993). These symptoms of thermoregulatory dysfunction in animals grazing ryegrass/ endophyte associations were first noted in lambs grazing an association with a high ergovaline concentration. However, there were also significant effects in lambs grazing wild-type associations which have lower ergovaline concentrations (Fletcher 1993b; Davies et al. 1993).

Little is known of the interaction of these toxic associations with short- and long-term fluctuations in environmental conditions and the response in animals grazing such associations. Furthermore, the lag time in animal response after introduction and removal to and from toxic pastures has not been studied for the different ryegrasslendophyte associations. Although increased respiration rate is a normal thermo-regulatory response to increasing body temperature the relationship between respiration rate and body temperature in animals grazing these toxic ryegrasslendophyte associations is unclear.

This paper reports on some of these relationships and effects and discusses their implications for the pastoral industry and future research.

\section{$M$ aterials and methods}

Thirty unshorn cryptorchid Coopworth lambs, with an average liveweight of $30 \mathrm{~kg}$ were allocated to 3 groups of 10, each with similar mean liveweights, base body temperatures and respiration rates. All lambs were identified individually and were then grazed as one mob on endophyte-free ryegrass/white clover pasture for 4 weeks. They had been grazing endophyte-free pastures for at least eight weeks prior to their selection. During the last week of this pre-trial grazing period body temperatures and respiration rates were recorded daily for all lambs. This was to establish base rates for these parameters over a range of ambient conditions. On 10 January 1994 at the end of this pre-trial period the lambs were fasted for 24 hours weighed and then 
each group of 10 was set stocked at $100 /$ ha on each of the three treatments. Paddocks (treatments) were selected on the sown ryegrass/endophyte association; ergovaline levels had been determined over summer and autumn in previous years (Table 1).

Table 1 Treatments and their history of ergovaline concentrations.

\begin{tabular}{lcccc}
\hline \multirow{2}{*}{ Treatment } & \multirow{2}{*}{ Endophyte } & \multicolumn{3}{c}{ Ergovaline concentration ppm } \\
& & Mar/Apr 92 & Jan 93 & Mar 93 \\
\hline 1 & 196 & $4.2^{\prime}$ & $1.4^{\mathrm{a}}$ & $2.3^{\mathrm{a}}$ \\
2 & Wildtype & $1.7^{\mathrm{b}}$ & $1.0^{\mathrm{a}}$ & $1.4^{\mathrm{b}}$ \\
3 & Nil & $0^{\mathrm{b}}$ & $0^{\mathrm{b}}$ & $0^{\mathrm{C}}$ \\
\hline
\end{tabular}

Values within a column with different superscripts are significantly different at $\mathbf{P}<0.05$.

Ergovaline concentrations and the differences between treatments varies over the season and tends to be higher in autumn than in summer.

The trial was conducted at Lincoln in January 1994, on 2-year-old pure Grasslands Nui ryegrass pastures. Any clover or weeds were sprayed out with 1 litre of Versatil/ha 6 weeks before grazing. There was an average of $4800 \mathrm{~kg} / \mathrm{ha}$ of herbage on each 0.1 ha paddock at the beginning of the trial, with no significant difference between treatments. Nitrogen was applied as urea in 3 split applications of 40 units $\mathrm{N} / \mathrm{ha}$ in spring 1993.

Rectal temperatures and respiration rates were recorded daily for individual animals on all treatments, between 1100 and 1300 hours, for the 35 days the lambs were grazing the trial, using Becton Dickonson digital clinical thermometers with a range of $32^{\circ} \mathrm{C}$ $42^{\circ} \mathrm{C}$. Respiration rates were measured by counting the number of respirations in $30 \mathrm{sec}$. using a programmable laboratory timer, with an audible alarm. Lambs were minimally restrained in specially constructed herringbone type bails during sampling and were off their paddocks for a maximum of 15 minutes.

Within the 35-day measurement period there was one 32-hour period of more intensive measurement. Between 1300 hours on 26 January and 2100 hours on 27 January body temperatures and respiration rates were recorded every 2-4 hours to determine the diurnal effect on animal response.

On 29 January 5 lambs from treatment 1 were swapped with 5 lambs with similar mean base temperatures and respiration rates from treatment 3 and measurements continued daily for 10 further days plus one sampling on 14 February.

Meteorological data recorded each hour was collected at appropriate times from an automatic meteorological station located within $1 \mathrm{~km}$ of the trial.
Ambient temperature was also recorded at regular intervals on site at each sampling.

\section{Results}

The lambs had grazed their paddocks to a low residual by the end of the 35 day grazing period leaving a mean residual of $1200 \mathrm{~kg} / \mathrm{DM} / \mathrm{ha}$. At such low allowances the intake of lambs would have been restricted for at least the last 10 days of the trial. Most lambs grazing treatment 2 had developed severe ryegrass staggers by the last week of the trial while those on treatments 1 and 3 showed no symptoms of staggers. All lambs lost weight during the trial but those on treatment 2 lost more.

Mean ergovaline concentrations taken from eight sampling days during the trial (Table 2) were similar to previous years at the same time (Table 1). There was a significant difference between treatments 1 and 2 but concentrations on treatment 1 were much lower than peak concentrations on the same treatment in autumn 1992 (Davies et al. 1993).

Table 2 Ergovaline concentrations (ppm) during trial 10/1/94 - 14/2/94 (mean of 8 days)

\begin{tabular}{lccc}
\hline Treatment & Endophyte & $\begin{array}{c}\text { Ergovaline } \\
\text { Mean }\end{array}$ & $\begin{array}{c}\text { concentration } \\
\text { Range }\end{array}$ \\
\hline$!$ & 196 & 2.1 & $1.3 \cdot 3.6$ \\
2 & Wild-type & 0.9 & $0.6-2.2$ \\
3 & Nil & 0 & 0 \\
\hline
\end{tabular}

Means of each treatment all differ significantly from each other $(P<0.05)$

Body temperature and respiration rates increased as ambient temperature increased but there was no difference between the three groups of lambs grazing the endophyte-free pasture in the 7 day pre-trial period.

Over the period IO-29 January covering an ambient temperature range of $15-28^{\circ} \mathrm{C}$, there was a small but significant $(\mathrm{P}<0.001)$ difference in both body temperature and respiration rate between the lambs grazing treatment 3 and those grazing treatments 1 and 2 but there was no significant difference between the lambs grazing treatments 1 and 2 (Figure 1 ). There was no significant interaction of treatment with ambient temperature within the range of $15^{\circ} \mathrm{C}-28^{\circ} \mathrm{C}$ although respiration rates in lambs from treatment 3 tended to increase more rapidly with increasing ambient temperature. Although body temperature and respiration rate increased with increasing ambient temperature only $50.4 \%$ and $48.3 \% \quad(\mathrm{P}<0.001)$ respectively of the day-today variation in the field was due to ambient temperature. There tended to be a closer relationship between ambient temperature and both body temperature and respiration 
rates in lambs from treatment 3 than in lambs from other treatments.

Variation due to other environmental variables in the field such as humidity, wind, and solar radiation were small and not significant alone; however, their combined influence in conjunction with ambient temperature could account for much of the variation.

During the 32-hour intensive sampling period there were again significant differences in body temperature and respiration rate between treatment 3 and treatments 1 and 2 but no difference between treatments 1 and 2 (Figure 2). Differences were significant at all sampling times for respiration rate. The differences varied throughout the day with changing ambient conditions and were greatest in early morning and afternoon. The significant differences in body temperatures or respiration rates between lambs from treatment 3 and treatments 1 and 2 remained overnight despite temperatures falling below $10^{\circ} \mathrm{C}$.

When the five lambs from treatment 1 were exchanged with the five lambs from treatment 3 the body temperatures of those transferred to treatment 3 initially rose above that of those remaining on treatment 1 while those transferred to treatment 1 fell in comparison with those rèmaining on treat $\overline{\text { Tent }}$ 3-(Figure-3)-From day two the temperatures of lambs transferred to treatment 1 began to rise in comparison to those remaining on treatment 3 while those transferred to treatment 3 fell in comparison with those remaining on treatment 1 . The body temperatures of those transferred to treatment 1 were significantly higher than that of those remaining on treatment 3 right through to day 14 after the crossover. Although the temperatures of those transferred to treatment 1 tended to fall, up until day six the temperature difference from those remaining on treatment 3 was not significant. From day six temperatures rose again in comparison to those on treatment 1. Overall there was a significant increase in body temperatures of lambs transferred to treatment 1 but no significant recovery in lambs transferred to treatment 3. There was a wide variation in respiration rates in lambs transferred between treatments with no significant differences between lambs transferred and those remaining on treatments.

Changes in body temperature over the 35-day
Figure 1 Relationship between ambient temperature and respiration rate and body temperature in lambs grazing 3 ryegrass/endophyte associations.

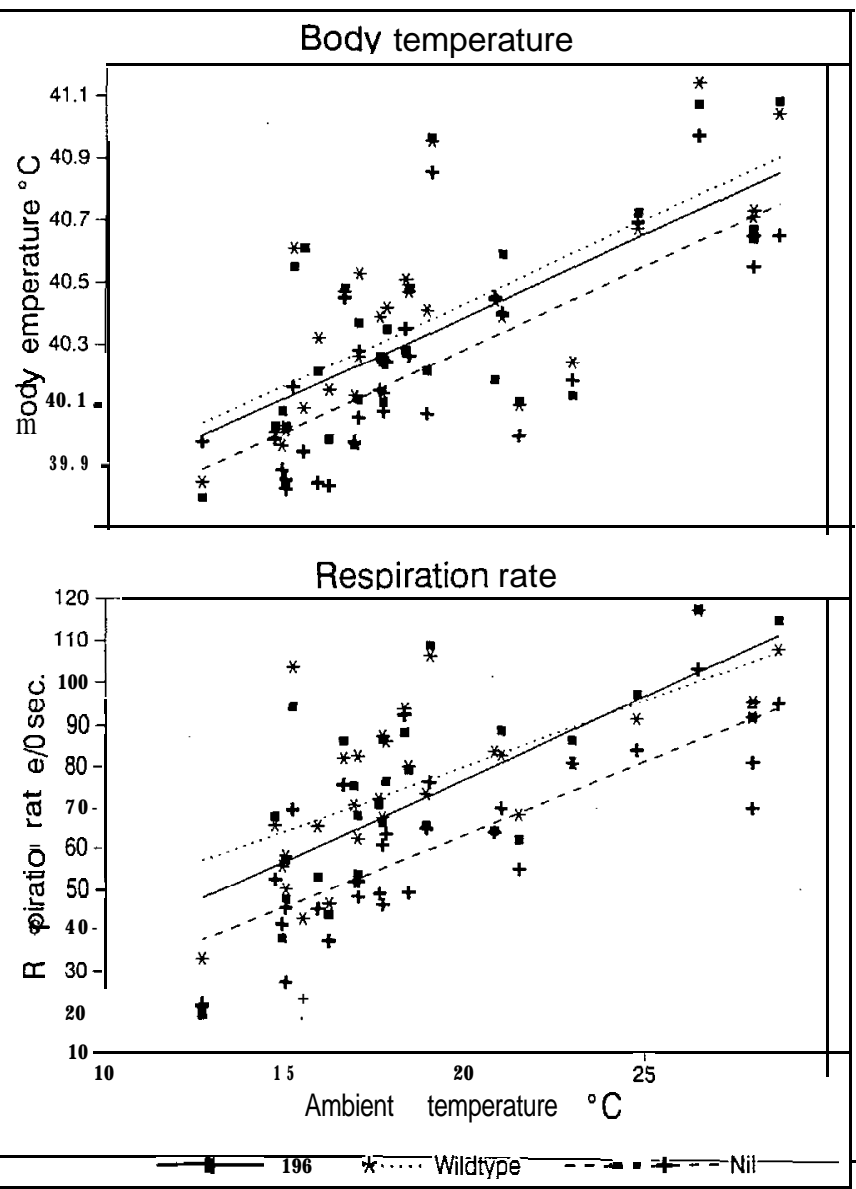

grazing period accounted for $65.6 \% \quad(\mathrm{P}<0.001)$ of the change in respiration rate of lambs in the field.

\section{Discussion}

Lambs were used in these studies because of their importance to the pastoral industry and because their small size make them a suitable model for other grazing animals allowing greater replication and making sampling easier and less stressful.

This research should be repeated with lactating dairy cattle as they are particularly sensitive to heat stress and tend to have a higher metabolic rate with consequent higher heat production (Mount 1979).

The mean body temperature of lambs grazing the endophyte-free treatments was lower during the trial period than the pre-trial period over a similar range of ambient temperatures. The maturity of the ryegrass 
and the absence of clover in the trial created lower quality pastures. This lower quality is believed to have lead to lower energy production, which was reflected in the lambs losing weight. Reduced heat production lowers the thermo-regulatory challenge which in turn would reduce the difference between the endophyte and endophytefree treatments (Mount 1979). Intake is believed to have had a major influence on initial changes in body temperatures of lambs which changed treatments in the crossover trial.

The unexpected increase in temperature of lambs transferred to the non-toxic treatment 3 is consistent with a sudden increase in intake on the more palatable ryegrass while the. initial decrease in lambs transferred to treatment 1 is consistent with a decrease in intake on the less-palatable and toxic ryegrass. This response gives some indication of the potential effect of intake on thermoregulatory challenge and could explain some of the day-to-day variation.

Respiration rates and body temperatures increased with increasing ambient temperature but other factors appear to have a large influence since ambient temperature accounted for only $50.4 \%$ and $48.3 \%$ of the increase in body temperature and respiration rate respectively. Factors such as relative humidity, wind (air movement) and solar radiation, as well pasture quality and intake, can all influence thermo-regulation in animals to various degrees (Mount 1979).

As the ambient temperature increases above an animal's thermo-neutral zone there is an increasing reliance on evaporative heat loss to regulate the body temperature. Evaporative heat loss reduces as humidity increases.

The toxic effects of endophyte and ergovaline on respiration rate, body temperature and other related responses occurred over the normal range of maximum spring summer and autumn temperatures in Canterbury. At the lower range of ambient temperature (thermoneutral zone) and humidity these effects may have little effect on production but the potential increases as ambient temperature and humidity increase.

Relative humidity on the trial site, latitude 43 " $38 \mathrm{~S}$, at $27^{\circ} \mathrm{C}$ in January was $49 \%$ (mean of 3 days) whereas in North Auckland (Warkworth Met. station number
A64463 latitude 36" 26S) it was $83 \%$ at a similar temperature in the same month. Severe heat stress has been observed in dairy cows grazing wild-type endophyte/ryegrass associations in warm humid conditions in North Auckland and Northland (M. Anderson (veterinarian) pers comm)

There is the potential for animals grazing current ryegrass/endophyte associations to develop various degrees of heat stress depending on geographical location and climatic conditions and this may explain some of the variability in summer and autumn ill-thrift syndrome.

The toxic potential is not restricted to the ryegrass/ 
endophyte associations with a 'high' ergopeptine alkaloid content but applies equally well to wild-type associations. This is evident from the results of this study where the response in lambs grazing the wild-type treatments was similar to those on the 'high' ergovaline treatments however other research has shown a significant differences between lambs grazing these ryegrass/endophyte associations (Fletcher 1993b).

Significant responses have been recorded in lambs grazing ryegrass/ endophyte associations with ergovaline concentrations of $0.5 \mathrm{ppm}$ (Fletcher unpubl.). The threshold level of ergovaline above which there is little increase in respiration rate or body temperature is less than $2 \mathrm{ppm}$ (Fletcher unpbl). The similar response of animals on treatment 1 and 2 of this trial supports this.

Any animal health, welfare or production response to increased ambient temperature which is mediated through increased body temperature or respiration rate, such as intake or heat stress, will occur at a lower ambient temperature in animals grazing ryegrass/ endophyte associations which produce ergopeptine alkaloids.

Increased respiration rates are a normal thermoregulatory response to increased-bay temperature in sheep, however the $34.4 \%$ difference in respiration rate not accounted for by body temperature suggests that at least some of the effect of ryegrass/endophyte associations and their toxins may be a direct toxic response rather than a response to increased body temperature.

Although further research into recovery time in animals removed from toxic pastures is needed, the absence of a clear significant recovery in the lambs transferred from treatment 1 (toxic) to treatment 3 (nontoxic) has implications for current and future research. It challenges the validity of using animals which have recently grazed ryegrass/endophyte associations as experimental subjects in endophyte-related research.

A significant animal response to low concentrations of ergovaline coupled with significant responses in lambs grazing wild-type associations suggests that any ergovaline is undesirable in our current wild-type endophytelryegrass associations and future ryegrass/ endophyte associations if we are to continue to improve animal health and production on ryegrass. Animal responses at low levels of endophyte and ergovaline, also highlight the importance of endophyte-free rather than low-endophyte controls in endophyte related-animal studies.

An understanding of the mechanisms through which the endophyte toxins affect physiological mechanisms will allow improved pasture and animal management ân maximise production.

Endophytes which do not produce lolitrem B or ergopeptine alkaloids have been identified (Latch pers.comm.; Christensen et al. 1993).These should eliminate the potential for heat stress and ryegrass staggers and improve animal production from ryegrass in the future.

\section{ACKNOWLEDGMENTS}

Meat Research and Development Council for support, C.G. Fletcher technical assistance, Dr D. Baird for statistical analysis and Dr Geoff Lane and E. Davis for ergovaline analysis.

\section{REFERENCES}

Belesky, D.P.; Stuedemann, J.A.; Plattner, R.D.; Wilkinson, S.R. 1988. Ergopeptine alkaloids in grazed tall fescue. Agronomy journal 80: 209-212.

Berde, B.; Schild, H.O. 1978. The ergot alkaloids and related compounds. In: Handbook of Experimental Pharmacology. Vol. 49, Springer-Verlag, New York. 
Christensen, M.J.; Leuchtmann. A.; Rowan, D.D.; Tapper, B.A. 1993. Taxonomy of Acremonium endophytes of tall fescue (Festuca arundinacea) meadow fescue (Festucapratensis) and perennial ryegrass (Lolium perenne). Mycological research 97: 1083

Davies, E.; Lane, G.A.; Latch, G.C.M.; Tapper, B.A.; Garthwaite, I.; Towers, N.; Fletcher, L.R.; Pownall, D.B. 1993. Alkaloid concentrations in field-grown synthetic perennial ryegrass endophyte associations. Proceedings 2nd International Symposium Acremonium/Grass Interactions. pp 72-76 D.E. Hume, G.C.M. Latch and H.S. Easton (Eds) Agresearch Grasslands, Palmerston North, New Zealand.

Fletcher, L.R.; Hoglund, J.H.; Sutherland, B.L. 1990. The impact of Acremonium endophytes in New Zealand, past, present and future. Proceedings of the NZ Grassland Association 52: 227-235.

Fletcher, L.R. 1993a. Grazing ryegrass/endophyte associations and their effects on animal health and performance. Proceedings 2nd International Symposium Acremonium/Grass Interactions: Plenary Papers pp 115-120 D.E. Hume, G.C.M. Latch and H.S. Easton ( $E d s)$ AgResearch Grasslands, Palmerston North, New Zealand.

Fletcher, L.R. 1993b. Heat stress in lambs grazing ryegrass with different endophytes. Proceedings 2nd International Symposium Acremonium/Grass
Interactions. pp 114-I 18 D.E. Hume, G.C.M. Latch and H.S. Easton (Eds) AgResearch, Grasslands, Palmerston North, New Zealand.

Mount, L.E. 1979. In: Adaption to thermal environment; man and his productive animals. Edward Arnold Ltd.

Rhodes, M.T.; Aldrich, C.G.; Paterson, J.A.; Kerley, M.S. 1989. The effect of endophyte-infected tall fescue and a dopamine antagonist on relative blood flow in sheep. Journal animal science. 67(Suppl 1): 286 (Abstr).

Rowan, D.D.; Tapper, B.A.; Sergejew,N.L.; Latch, G.C.M. 1990. Ergopeptine Alkaloids in EndophyteInfected Ryegrasses and Fescues in New Zealand. Proceedings of the 1st International Symposium on Acremonium/Grass Interactions. pp 97-99.

Stuedemann, J.A.; Thompson, F.N. 1993. Management strategies and potential opportunities to reduce the effects of endophyte-infested tall fescue on animal performance. Proceedings 2nd International Symposium Acremonium/Grass Interactions: Plenary Papers pp 103-114 D.E. Hume, G.C.M. Latch and H.S. Easton ( $E d s$ ) AgResearch Grasslands, Palmerston North, New Zealand.

Thompson, F.N.; Stuedemann, J.A. 1993. Pathophysiology of fescue toxicosis $\mathbf{m}$ : Acremonium/ Grass Interactions. Eds. R. Joost and S. Quisenberry. Elsevier. 